\title{
Local Taxation of Tourism in the Context of the Collaborative Economy - Case Study from the Czech Republic
}

\author{
LUCIE PlZÁKOVÁ \& PETR STUDNIČKA
}

\begin{abstract}
Tourism management has undergone significant changes in recent years under the influence of two factors: the strengthening of the fiscal decentralization approach and the development of a collaborative economy that significantly affects the tourism market, both on the supply and demand side. Tourism taxes are one of the management tools on the local level. The paper focuses on innovation in the act on local charges and fees so that it meets the requirements of the current state and the expected development in the future, laying emphasis on the use of digital platforms in tourism. The proposed and accepted legal regulation will bring the Czech self-government many advantages such as i) extended powers for self-government; ii) increased revenues to the municipalities' budgets; iii) the update of such groups of tourists that are exempted from local taxation, and iv) the liability to ensure local taxation for all types of objects providing short-term temporary accommodation.
\end{abstract}

Keywords: $\bullet$ collaborative economy $\bullet$ tourism $\bullet$ local taxes $\bullet$ peer-topeer accommodation $\bullet$ innovation legal norm

Correspondence AdDress: Lucie Plzáková, Ph.D., Assistant Professor, Institute of Hospitality Management in Prague, Travel and Tourism Department, Svídnická 506, Prague 8, 180 00, Czech Republic, email: plzakova@vsh.cz. Petr Studnička, Ph.D., Institute of Hospitality Management in Prague, Hotel Management Department, Svídnická 506, Prague 8, 180 00, Czech Republic, email: studnicka@vsh.cz.

https://doi.org/10.4335/19.1.65-89(2021)

ISSN 1581-5374 Print/1855-363X Online C) 2021 Lex localis

Available online at http://journal.lex-localis.press. 
Tourism has become the face of collaborative economy, whether in accommodation (Airbnb, HomeAway, etc.), boarding (Kitchen Surfing, MealSharing, etc.), transport (Uber, Blabla Car, Car2Go, Fun2Boat, etc.), and education and information (Meetup, I like local, etc.) or travelling itself (TripTogether, Wandermates, etc.). New trends in tourism involve tourism demand individualization, the need for greater flexibility in decision-making, accelerated selection, booking and payment for services, and last but not least, immediate feedback from customers. All of this is possible due to the rapid development of information and communication technologies (ICT). However, it becomes apparent that the tax system in many destinations of tourism is not prepared for this innovation and that an innovation in the legislative environment is a slow process compared with innovations in the area of ICT.

The taxation of tourism services does not differ too much from other economic areas and always corresponds with the tax system in the country concerned. The greatest volume of revenues flows mostly through value added tax and personal or corporate income tax. The rate of the taxation of tourism services differs both in individual countries and within the European Union. Some authors deal with the regulation of direct or indirect taxes in relation to the tourist industry and their influence on the development of demand and the total performance of the industry. Jensen \& Wanhill (2002) deal with the regulation of the rate of value added tax on accommodation services in individual EU countries, with emphasis put on the situation in Denmark. Sheng (2011) deals with the taxation of tourism services and the taxation of other economy performance that is not dependent on tourism in the tourist destination. Other authors deal with the regulation of taxes in tourism in relation to the environment and transport or the taxation of tourism services in a specific territory (for more see Palmer \& Riera, 2003; Palmer-Tous at al., 2007; Gricar \& Bojnec, 2017). The issue of tourism local taxation is researched by Steve Burns (2010), who deals with the local taxation of tourism in the United Kingdom; he uses a sample of 25 questionnaire responses to show the importance of taxation and its influence on local authorities' demand for the financial support for the development of tourism in the localities concerned. Saptomo (2017) deals with the matter of how to increase regional revenues through tourism in Indonesia, and Afonso (2016) deals with the subject: The Equity of Local Sales Tax Distributions in Urban, Suburban, Rural, and Tourism Rich Counties in North Carolina. However, little attention is paid to the local taxation of tourism services in relation to the location (or tourist destination). At present, there are no studies to address the changes in tourism due to the collaborative economy in relation to local residents and communities. The local taxation of tourism services is one of the very significant tools of local self-government and can be used for saturating the increased burden on public spaces and the use of public property and services in the territory of the municipality not only by residents but also by non-residents. 
The authors of the article focus on the regulation of the local taxation of accommodation, or a stay, which, due to new trends within the collaborative economy realized on the basis of a peer-to-peer business model, is a highly discussed and topical subject.

The aim of this paper is to identify problems of the local taxation of tourism services in the context of the collaborative economy and to suggest an innovation in the legal regulation using the Czech Republic as an example. The innovation should bring the benefits for: a) the politics - strengthening the principal of the subsidiarity; increasing revenues to the municipalities budgets; decreasing the taxes administration; b) the practice - setting a sense of confidence across the short-term accommodation market; increasing public sector support for the quality of public services and infrastructure by increasing the budgets of municipalities; decreasing the level of administration, and for c) the society at all - increasing investments of the municipalities into public services and infrastructure; building a sense of solidarity and fairness between residents and visitors. The hypothesis can be formulated as: The development of the collaborative economy initiates the need to innovate legislation in the area of setting local tourism taxation leading to a settlement of conditions at the tourism market.

\section{$2 \quad$ Literature overviews}

The genesis of the definition of the collaborative economy is long and its beginning can be seen in history. A barter trade has characteristics of sharing, but of such sharing that takes place on the basis of reciprocity and with no compensation in money. Also, in the case of a barter, social interactions took place in the society and relations between the provider and the recipient were built on both sides. Also, the sharing economy, called other terms such as on-demand economy, we-conomy, gig economy, access economy, participative economy and/or collaborative economy, has this characteristic in common. To be more specific, and for the purposes of this study, the basic terms are defined hereinafter.

Collaborative economy is based on collaborative consumption when Felson and Spaeth (1978: 614) defined this term for the first time as: "Actors of collaborative consumption events in which one or more persons consume economic goods or services in the process of engaging in joint activities with one or more others". It was necessary to respond to this definition in the process of transformation into the global company, when new technologies were developed; they manifested themselves most noticeably in widely used Internet access, the creation of social networks, and the massive use of online marketing. All of this had, and still has, an influence on a change in consumer behaviour. And this has also changed the original perception of collaborative consumption. Botsman and Rogers (2011) responded to these changes by their article: "What is mine is yours: How 
collaborative consumption is changing the way we live" and later Botsman (2014: 24) defined collaborative consumption as: "A system activating the untapped value of assets through models and marketplaces that enable greater efficiency and access". A detailed overview of the genesis of terms and approaches to the sharing economy concept is given by Dredge and Gyimóthy (2017). Concerning today's concept of collaborative consumption and also within the entire collaborative economy functioning model, also another term must be given; this is "peer-to-peer". Peer-to-peer is used from various points of view: the peer-topeer economy, a peer-to-peer business model (Bauwens et al., 2012), peer-to-peer markets (Einav et al., 2016), peer-to-peer trading, peer-to-peer networks (Gansky, 2010; Karlsson \& Dolnicar, 2016; etc.), and peer-to-peer platforms (Wirtz et al., 2019). The essence of peer-to-peer is a client-client relation, where the exchange of goods and services takes place via digital platforms without the presence of another mediator such as a shop, an agency, a bank, and others. It is digital platforms and their role in the tourism industry that plays a significant role.

The separation of the sharing economy term and the collaborative economy term is supported by Gössling and Hall (2019: 76), for example; they state that "sharing refers to predominantly private, and often non-commercial transactions, while the collaborative economy is focused on mediating commercial business-to-peer exchanges, virtually always involving platforms owned by global corporations". Dolnicar (2019) points out that the sharing economy, collaborative consumption and collaborative economy terms are not always used correctly. These terms replace the general term, which is sometimes more accurate; this term is peer-topeer trading with the use of digital platforms (collaboration) or without using them (sharing). The collaborative economy term will be used in connection with the provision of all services within tourism on the basis of the general peer-to-peer trading model in this article.

The collaborative economy is built on changes and supports or generates changes at the same time: in the society, in consumer behaviour, in technologies, in economy, in communication, in marketing, in management, and in other spheres of human activities. Some changes in connection with the sharing economy and peer-to-peer business models are mentioned by the authors Lamberton and Rose, (2012); Zervas et al., (2017); and Caldieraro et al., (2018). Changes take place in relation to all actors who are engaged in the collaborative economy in tourism. The most significant actors are generally customers, service providers, and digital platform providers (Benoit et al., 2017). Dredge and Gyimóthy (2017: 9) specify a group of actors in collaborative economy in tourism as follows: Consumers; Accommodation providers; New service entrepreneurs; Local residents and communities; Incumbent industry operators and groups; Collaborative economy platforms; Governments and Other publics. However, the relation between the customer, the service provider, and the digital platform provider is essential in the peer-to-peer business model, the authors focus especially on Consumers, 
Governments (at all levels - national, regional, and local), and Local residents and Community. It is not in the authors' interest to divide residents into those who profit economically from the expansion of the collaborative economy in the locality concerned, this means that they have tangible or intangible property and are willing to share it or to do trade with it via digital platforms, and those who do not have such property. The following question is in the spotlight concerning research: Is the local taxation of tourism services mandatory for all tourists accommodated in the destination? Did the need to adjust the legal norms, especially in the area of accommodation, to ensure that the legal environment is the same for all who are involved not arise when peer-to-peer trading emerged? How do municipalities manage to care for public spaces when the intensity of tourism increases and the extended services supply via digital platforms contributes to it? The authors are looking for innovation in the local tourism taxation so that increased costs of public services and property, the basic scope of which is primarily built and provided for the residents in the municipality concerned, can be financed from revenues that flow directly into the municipality budget.

\subsection{Taxation of tourism}

Tourism has many positive economic impacts such as the support of small and medium enterprises, job creation, tax revenues, etc. However, the development of tourism is not free property, as mentioned by Mak (2006: 251), who adds: "The production of tourism goods and services requires resources which may have to be diverted from other economic uses. The net benefit from tourism development depends critically on how a destination designs its public finance/revenue system to tax travel and tourism." The introduction of tourist taxes, charges and fees at municipal level has been included in the tax system of many countries for a long time. In the Czech Republic the history of the introduction of the first local fee in the spa town of Carlsbad dates back to the year 1475 .

The taxation of tourism services can be divided into two categories: i) general taxes, which do not differentiate between economic activities; examples include value added tax, corporate and personal income taxes, road tax, property tax, etc., and ii) specific taxes, charges and fees, which are directly related to the economic activity: tourism; examples may be a fuel surcharge in air transport, a local fee for a stay (bed/lodging taxes), visa fees, charges on entering and leaving a country, entrance fees, and others.

This article focuses on local taxes, charges and fees, i.e. such taxes, charges and fees where $100 \%$ of them belong to the municipality in which the charge/fee is imposed on the activity, and, in relation to the collaborative economy, these are especially fees for accommodation and for a stay. Local charges and fees rank among local taxes (for more about the legal regulation of the terms see Radvan, 
2012) and decisions on their introduction are usually taken by municipalities. Municipalities have the right to appropriate their own resources within the economic policy of the country on the basis of the European Charter of Local SelfGovernment (1985) and may dispose of them freely within their powers. At least a part of financial resources originate from local taxes, charges and fees and local communities may establish their rates within the law. Local taxes, charges and fees must meet four basic criteria:

a) the appropriation criterion - the tax yield belongs to municipalities;

b) the rate criterion - the tax rate is established by the municipality;

c) the collection criterion - the tax is administered by the municipality; and

d) the decision-taking criterion - the decision on the tax base is taken by the municipality. (Radvan, 2012).

In recent years there has been a rapid increase in the number of municipalities applying local taxes (charges and fees) related to the performance of the tourism, hotel and spa industries in the European Union member states. According to the research carried out by European Tourism Association (2012) and Ranson (2014), there has also been an increase in local charge and fee rates and their development is also monitored in the context of tax reliefs and reduced VAT tax on accommodation services. Sixteen out of 28 European Union member states have introduced a local tax (local fee/charge) related to tourism and accommodation facility performance. A rate is usually determined as an amount per person and night or, in some cases, as a percentage of the total price for accommodation. Local charges and fees are only rarely related to a certain purpose (Germany and Austria) so that the collected money generated from them must be reinvested in the support of the development of tourism in a specific territory.

The setting up of local taxes for tourism is the imposition of a charge on a "foreign" person from the viewpoint of the municipality. The payer of a local charge or tax is (directly or indirectly) a tourist, i.e. a non-resident that is not among the electors in the municipality concerned. Theoretically, the amount of the local taxation of tourism may become a tool of a competitive fight between destinations. The Balearic Islands can be given as an example; the number of tourists decreased by $10 \%$ during the eight months that followed the introduction of daily "eco-tax" in May 2002 (Mak, 2006). The payment of local taxes on accommodation is usually a very frequent argument of traditional service providers in relation to accommodation providers within the collaborative economy. This argument is that traditional accommodation is more expensive, among other things, also due to the payment of local taxes, but a "private" accommodation provider making a deal via a digital platform does not always have to pay the local tax. The introduction of local taxes in connection with tourism has many causes. Mak (2006: 253) states the following: "Destinations tax tourism for at least four reasons: (i) to expand and diversify their tax base; (ii) to export taxes to non-resident tourists; (iii) to tax away excess profits or economic 
rents from tourism to benefit residents; and (iv) to correct for market failure." The last stated reason relates to negative externalities of the realization of tourism in a territory; for example, negative environmental impacts. The following Table 1 gives the types of local taxes, charges or fees in relation to tourism in selected countries with relation to the Czech Republic - neighbouring Slovakia, the Free State of Saxony in the Federal Republic of Germany, and Land Salzburg in Austria. (Note: The neighbouring Poland is not included in the overview by reason of inconsistency and ongoing changes in the regulation of the local taxation of tourism).

Table 1: The type of local taxes (charges/fees) in relation to tourism in selected countries in relation to municipality budgets

\begin{tabular}{|c|c|c|c|}
\hline \multirow{2}{*}{$\begin{array}{l}\text { Country } \\
\text { (region) }\end{array}$} & \multicolumn{2}{|l|}{ Income side } & \multirow{2}{*}{$\begin{array}{l}\text { Expenditure side } \\
\begin{array}{l}\text { For a certain } \\
\text { purpose }\end{array} \\
\end{array}$} \\
\hline & Taxation form & Rate & \\
\hline Czech Republic & $\begin{array}{l}\text { Local fee for a spa } \\
\text { or recreation stay } \\
\text { Local fee for an } \\
\text { accommodation } \\
\text { capacity }\end{array}$ & $\begin{array}{l}\text { Max. } 0.55 \\
€ / \text { person/day } \\
\text { Max. } 0.22 € / \text { bed } \\
\text { used / day }\end{array}$ & No \\
\hline Slovakia & $\begin{array}{l}\text { Local tax on } \\
\text { accommodation }\end{array}$ & $\begin{array}{l}\text { No minimum or } \\
\text { maximum amount } \\
\text { established; it } \\
\text { depends on the } \\
\text { decision taken by the } \\
\text { municipality }\end{array}$ & $\begin{array}{l}\text { No, but there is } \\
\text { a relation to the } \\
\text { amount of the } \\
\text { subsidy for } \\
\text { tourism } \\
\text { organisations }\end{array}$ \\
\hline $\begin{array}{l}\text { Austria } \\
\text { (Salzburg) }\end{array}$ & $\begin{array}{l}\text { General local tax } \\
\text { Spa fee }\end{array}$ & $\begin{array}{l}1.50 \text { and } 2.00 € / \\
\text { person / overnight } \\
\text { stay } \\
0.60-3.00 € / \text { person / } \\
\text { overnight stay }\end{array}$ & $\begin{array}{l}\text { Yes, to support } \\
\text { the development } \\
\text { of tourism }\end{array}$ \\
\hline $\begin{array}{l}\text { Germany } \\
\text { (Saxony) }\end{array}$ & $\begin{array}{l}\text { Spa fee } \\
\text { Bed tax }\end{array}$ & $\begin{array}{l}\text { No minimum or } \\
\text { maximum amount } \\
\text { established; it } \\
\text { depends on the } \\
\text { decision taken by the } \\
\text { municipality }\end{array}$ & $\begin{array}{l}\text { Yes, to support } \\
\text { the development } \\
\text { of tourism }\end{array}$ \\
\hline
\end{tabular}

Source: Authors' own elaboration, 2019

\subsection{Local taxation of tourism overlapping the collaborative economy}

The new type of business connected with the collaborative economy is a result of innovations that are created with the emergence of Industry 4.0. and the need to innovate the legal environment that has come. Digital platforms and new service providers represent a new and completely different way of business and it was 
impossible to envisage this at the time when the currently valid legislation was created (Kaplan, 2014). The regulatory framework for activities of the collaborative economy in tourism is a challenge with which all towns worldwide are faced. In some cases, regulatory measures are very strict, with the aim of reducing this activity (especially the lease of accommodation or the provision of transport services) by reason of its negative impact on traditional service providers and by reason of the exponential growth of the number of tourists in destinations, causing the danger of an environmental disaster, the devastation of cultural monuments, and a threat to the basic functions of the local community. In addition to economic impacts of the collaborative economy, the matter of a relation between tourists and residents, the growing burden on a territory, and shares of the responsibility of three groups: a) residents, b) tourists accommodated in traditional accommodation facilities, and c) tourists accommodated via digital platforms comes to the fore.

Local communities and residents are impacted both positively and negatively by the development of the collaborative economy in tourism depending on the intensity of tourism in the destination. Positive impacts may be seen in the support of local business, the establishment of a closer relation between residents and tourists, the expansion of tourist zones also outside the mostly exposed centers of towns, and, as also stated by Kaplan \& Nadler (2017: 105-106), "it has also exhibited a strong philanthropic streak which includes participating in community-service projects...". Increasing the prices of real estate, pushing residents out of the centers of towns, changing the structure of services provided in the tourist parts of towns, and, last but not least, increasing the consumption of public property and services the financing of which is provided by the local selfgovernment can be considered as negative. The need for tax accommodation services, the lease of which is realized via a digital platform, began to be discussed in San Francisco, i.e. the place where the whole idea of sharing accommodation was created, as early as the year 2012. John Coté summarizes the opinions of main city representatives in his article in SF Gate, stating that there is no need to alter the act on local charges and fees but that it must be innovated (Coté, 2012). Guttentag (2016: 8) states that "Also, in many jurisdictions Airbnb does not yet charge the accommodation taxes that traditional accommodations often levy". Local government thus often discuss the payment of local taxes, charges and fees with digital platforms. Municipalities especially argue that the need to finance the local infrastructure and public property and services is increased; in addition to residents, also visitors use them irrespective of the type of the accommodation facility where they stay. However, towns often meet with how the legal norm is set because it is unambiguous in relation to accommodation within the collaborative economy. At this moment it depends on the digital platform, the lessor and also the customer, whether he is willing to pay a local fee for accommodation and/or a stay also in this case, and this becomes rather a matter of responsibility and solidarity. Airbnb (the largest of the digital platform 
representatives) informs its customers on its website that local charges and fees connected with their stay may be collected in towns. Airbnb (2019) states that "Currently, Airbnb is collecting and remitting taxes on behalf of the host in the following locations: Bermuda, Brazil, Canada, France, Germany (Dresden, Dortmund, and Frankfurt a. M.), India, Italy, Mexico, Netherlands, Portugal, Switzerland, and USA." An example from the Czech Republic is given in the next chapter; for more about examples from the cities of New York and San Francisco see Kaplan \& Nadler (2017).

\subsection{Local taxation of tourism - the Czech Republic}

In the conditions of the Czech Republic, the principle of fiscal decentralization and the characteristics of local taxes are only met by property tax and local charges and fees; $100 \%$ of the collected amount is municipality budget revenues. In the Czech Republic the local taxes represent only approx. $1.5 \%$ of the total tax revenues (Ministry of Finance of the Czech Republic, 2019). There are differences between taxes and local charges and fees (Tab. 2).

Table 2: Differences between property tax and local charges and fees

\begin{tabular}{|c|c|c|}
\hline Category & Property tax & Local charges and fees \\
\hline Character & Mandatory & Optional \\
\hline Impact on the yield & $\begin{array}{l}\text { Generally binding } \\
\text { regulation - tax rate, } \\
\text { exemption, and local } \\
\text { coefficient }\end{array}$ & $\begin{array}{l}\text { Generally binding regulation } \\
\text { - decision taking and } \\
\text { introduction, exemption, and } \\
\text { rate }\end{array}$ \\
\hline Administration & $\begin{array}{l}\text { The Financial } \\
\text { Administration of the Czech } \\
\text { Republic }\end{array}$ & $\begin{array}{l}\text { Individual municipal } \\
\text { authorities }\end{array}$ \\
\hline $\begin{array}{l}\text { Total annual yield } \\
\text { (2017) }\end{array}$ & CZK 10.5 milliard & CZK 5 milliard \\
\hline
\end{tabular}

Source: The Ministry of Finance of the Czech Republic, 2019.

The municipality councils within their separate powers through a generally binding regulation set the rates of local charges and fees and other details (the creation and termination of the liability to pay a fee or charge, time limits for the performance of the obligation to report, due dates, reliefs, or exemptions). The law defines some cases and persons that are exempted from the payment of a local charge or fee and, in some cases, enables a municipality to set a flat fee by a generally binding regulation or by agreement. Local charges and fees proceedings are conducted by the municipal authority within its delegated powers.

According to Act No. 565/1990 Coll. (2019), on local charges and fees, as amended, two local charges and fees have had a direct relation to accommodation services until the end of the year 2019. These were a local fee for a spa or 
recreational stay and a local fee for an accommodation capacity. The first of these fees was paid by natural persons that stayed temporarily and for a consideration in spa places and in places of concentrated tourism for the purpose of treatment or recreation unless these persons proved a different reason for their stay. The other fee was paid by an accommodation provider, which was a natural or legal person that provided temporary accommodation, and municipalities collect it in facilities designated for temporary accommodation for a consideration unless this is an accommodation capacity in facilities used for the temporary accommodation of students and pupils, in medical and spa facilities unless these are used as hotel facilities, and in facilities used for social and charitable purposes. Differences between the two local fees are given in Tab. 3 .

Table 3: Differences between the local fees in relation to tourism in the Czech Republic (before innovation)

\begin{tabular}{|c|c|c|}
\hline $\begin{array}{l}\text { Characteristics } \\
\text { of the fee }\end{array}$ & $\begin{array}{l}\text { Local fee for a spa or } \\
\text { recreational stay }\end{array}$ & $\begin{array}{l}\text { Local fee for an } \\
\text { accommodation capacity }\end{array}$ \\
\hline Subject & $\begin{array}{l}\text { Payer: a natural person } \\
\text { Payer: an accommodation } \\
\text { provider (a natural or legal } \\
\text { person) }\end{array}$ & $\begin{array}{l}\text { Payer: an accommodation } \\
\text { provider (a natural or legal } \\
\text { person) }\end{array}$ \\
\hline Object & $\begin{array}{l}\text { A stay of specific natural } \\
\text { persons in selected places }\end{array}$ & A bed capacity used \\
\hline Fee base & $\begin{array}{l}\text { Temporary presence in selected } \\
\text { places for the purpose of a spa } \\
\text { or recreational stay (days of } \\
\text { stay) }\end{array}$ & $\begin{array}{l}\text { An accommodation capacity } \\
\text { used in selected places (a bed } \\
\text { occupancy rate) }\end{array}$ \\
\hline Rate & Up to $15 \mathrm{CZK} /$ person/day & Up to $6 \mathrm{CZK} /$ bed used / day \\
\hline $\begin{array}{l}\text { Flat rate } \\
\text { charging }\end{array}$ & $\begin{array}{l}\text { A lump sum per week, month or } \\
\text { year - no alternative }\end{array}$ & $\begin{array}{l}\text { A lump sum per year - after } \\
\text { acceptance by the payer }\end{array}$ \\
\hline $\begin{array}{l}\text { Local } \\
\text { competence to } \\
\text { assess }\end{array}$ & $\begin{array}{l}\text { The municipality in the territory } \\
\text { of which temporary } \\
\text { accommodation is provided }\end{array}$ & $\begin{array}{l}\text { The municipality in the territory } \\
\text { of which temporary } \\
\text { accommodation is provided }\end{array}$ \\
\hline Fee period & $\begin{array}{l}\text { No fee period; this fee is related } \\
\text { to every commenced day of the } \\
\text { stay (except for the arrival day); } \\
\text { week, month or year in the case } \\
\text { of flat rate charging }\end{array}$ & $\begin{array}{l}\text { No fee period; this fee is related } \\
\text { to every bed used and day; year } \\
\text { (period of } 12 \text { consecutive } \\
\text { calendar months) in the case of } \\
\text { flat rate charging }\end{array}$ \\
\hline $\begin{array}{l}\text { Exemption } \\
\text { from the duty } \\
\text { to pay the fee }\end{array}$ & $\begin{array}{l}\text { Blind and impotent persons and } \\
\text { severely handicapped persons to } \\
\text { whom level III for } \\
\text { extraordinary benefits has been } \\
\text { awarded and their guides, } \\
\text { soldiers in a compulsory } \\
\text { military service and persons } \\
\text { performing a civilian service, } \\
\text { persons under } 18 \text { years of age }\end{array}$ & $\begin{array}{l}\text { An accommodation capacity in } \\
\text { facilities used for the temporary } \\
\text { accommodation of students and } \\
\text { pupils, an accommodation } \\
\text { capacity in medical or spa } \\
\text { facilities unless used as hotel } \\
\text { facilities, and an } \\
\text { accommodation capacity in } \\
\text { facilities used for social and }\end{array}$ \\
\hline
\end{tabular}




\begin{tabular}{|c|c|c|}
\hline $\begin{array}{l}\text { Characteristics } \\
\text { of the fee }\end{array}$ & $\begin{array}{l}\text { Local fee for a spa or } \\
\text { recreational stay }\end{array}$ & $\begin{array}{l}\text { Local fee for an } \\
\text { accommodation capacity }\end{array}$ \\
\hline & $\begin{array}{l}\text { and over } 70 \text { years of age, and } \\
\text { persons being subject to child } \\
\text { benefits are not subject to this } \\
\text { fee }\end{array}$ & $\begin{array}{l}\text { charitable purposes are not } \\
\text { subject to this fee }\end{array}$ \\
\hline $\begin{array}{l}\text { Liabilities of } \\
\text { fee subjects } \\
\text { other than } \\
\text { pecuniary }\end{array}$ & $\begin{array}{l}\text { An accommodation provider } \\
\text { must keep a book of records in } \\
\text { writing and the records must be } \\
\text { arranged in chronological order; } \\
\text { this book is retained for } 6 \text { years } \\
\text { from the last entry of a record }\end{array}$ & $\begin{array}{l}\text { An accommodation provider } \\
\text { must keep a book of records in } \\
\text { writing and the records must be } \\
\text { arranged in chronological order; } \\
\text { this book is retained for } 6 \text { years } \\
\text { from the last entry of a record }\end{array}$ \\
\hline
\end{tabular}

Source: Authors' own elaboration using Pelc (2012: 1-17).

In the Czech Republic, it was possible to collect $21 \mathrm{CZK} /$ person/day (0,82 EUR when $1 E U R=25,64 \mathrm{CZK}$ ) concerning the two local fees, which was a low amount when compared with foreign destinations of tourism. The maximum rate of a local fee for a spa or recreational stay was CZK 15 (0,59 EUR) per person and every commenced day of the stay unless the day is the arrival day. The total annual yield from this local fee reached CZK 406.9 million (15,87 mil. EUR) and this fee was collected in 956 municipalities (15.2\% of the total number of municipalities in the Czech Republic, 2019). The maximum rate of a local fee for an accommodation capacity was $6 \mathrm{CZK} / \mathrm{bed} / \mathrm{day}(0,23 \mathrm{EUR})$. The total annual yield from this local fee reached CZK 288.2 million (11,24 mil. EUR) and this fee was collected in 1,513 municipalities ( $24.2 \%$ of the total number of municipalities in the Czech Republic, 2019).

A problem of the version of the act on local charges and fees before innovation was the definition of an object where the fee for an accommodation capacity could be collected. Act No. 565/1990 Coll. provided that a fee for an accommodation capacity was collected "in municipalities and towns in facilities designated for temporary accommodation for a consideration". Such a definition showed to be unclear to discriminatory over the course of time. Experience showed that socalled apartment housing or facilities leased for a consideration within the sharing (or rather collaborative) economy avoided paying this fee in this way. It was appropriate that the fee concerned could be collected by more types of accommodation facilities because only a bed capacity in facilities designated for temporary accommodation for a consideration by the building regulations (a final building approval / an occupancy permit decision) was subject to a local fee. It was therefore appropriate to redefine the purpose of an accommodation facility from facilities "designated" for temporary accommodation to facilities "used" for temporary accommodation.

To support the necessary innovation in the regulatory norm, an analysis was carried out using the capital city of Prague as an example with the aim of showing 
the development of the peer-to-peer accommodation supply in connection with its basic indicators such as an occupancy rate and RevPAR (Revenue Per Available Room). A comparison between these performance indicators and the traditional hotel accommodation market is also interesting.

\section{3}

\section{Research}

The aim of the research part is to find such outcomes upon which the hypothesis could be rejected or confirmed and to identify problems of the local taxation of tourism services in the context of the collaborative economy and to suggest an innovation in the legal regulation.

\subsection{Methodology and data}

To fulfill the goal of the study, the main findings of which are presented in this article, the analysis of quantitative and qualitative data was supported. A mixture of primary sources and secondary sources was used to collect the data. The period under consideration was 2015-2019.

Primary data was collected within two groups:

1. Representatives of municipalities, where semi-structured interviews were done. Sixty-two municipalities' representatives were requested within the preselected group based on the following criteria: i) must belong to the key tourist destinations in the Czech Republic that means: Prague, UNESCO sites, spa destination, mountain destination, destination near by a water area or significant city destination AND ii) the municipality must collect at least one of two local fees. These municipalities create only $1 \%$ of the total number of Czech municipalities, but they collected more than $78 \%$ of the total amount of revenues that came from the both local tourism fees. $58 \%$ of them (36 municipalities) had willingness to share their experiences and opinions. Divided into categories, the respondents were: capital city of Prague, 5 UNESCO sites, 5 city destinations, 7 destinations nearby water area, 8 mountain destinations and 10 spa destinations. The cooperating municipalities in the study covered $66.5 \%$ of the total revenue from both local fees earned yearly in the Czech Republic. That can be considered as a representative sample for the research.

The main research questions towards representatives of municipalities were a) whether they welcome the innovation of law on local charges and fees, $b$ ) what is the share of the municipality budget invested into tourism development (this question corresponded with an expected argument from the providers side for not paying the fee), and c) what is the level of accommodation providers' willingness to pay a local fee. 
2. Providers of traditional collective accommodation establishments were the second interviewed group. 15 subjects were requested: 14 providers of collective accommodation establishments and one professional association The Czech Association of Hotels and Restaurants that protects and promotes the interests of its members. The association invited its members from the key destinations to cooperate on the study. 42 owners of accommodation establishments were asked for an interview and 14 were willing to cooperate.

Providers of accommodation facilities were asked if they pay local taxes (under the guarantee of anonymity), if not, why, and if they welcome innovation of law.

The primary data were evaluated by frequency and content analysis. Based on the outcomes, it should be able to reject or confirm the hypothesis.

Secondary data were collected from public sources such as the Czech Statistical Office (CZSO), the MONITOR database of the Ministry of Finance of the Czech Republic and from AirDNA supplemented with an expert estimate. A key analysis is then the development of revenues from a local fee for an accommodation capacity and from a local fee for a spa or recreational stay in relation to the number of realized overnight stays in collective accommodation establishments (CAE) and in such objects that realized the lease of accommodation capacities via the Airbnb and HomeAway digital platforms in the conditions of the collaborative economy in Prague. The capital, Prague, was chosen as an example due to the intensity of the collaborative economy in tourism being the highest and the data available.

\subsection{Local tourism fees - municipalities viewpoint}

Twenty-eight of the interviewed municipalities (that is $78 \%$ ) collected both local fees in a direct relation to tourism: local fee for spa or recreational stay and local fee from accommodation capacity. If we look back to the research questions stated above we can consider that municipalities preferred to maintain the current maximum rate for both fees and from 51,4\% they supported to merge both local tourism fees in one. However, there was no clear support for the innovation of the legal norm, in case of $95 \%$ the municipalities have made some changes in setting up the conditions of local tourism taxes during the last ten years. Mostly they increased the rate of the fee, one or both.

The question about the share of municipality budget which was invested into tourism development has shown a very high variability, see Tab. 4. Very significant secondary output from this question is that it is not clear what is exactly meant by "tourism costs" in the municipality budget. This is an issue that has to be solved in the near future by the Ministry for Regional Development in 
L. Plzáková \& P. Studnička: Local Taxation of Tourism in the Context of the Collaborative Economy - Case Study from the Czech Republic

cooperation with the Ministry of Finance. The problem of the very low level of reinvested money earned from tourism fees into tourism development has very often been mentioned by accommodation service providers as an argument for not paying everything they should be paying.

Table 4: The share of municipality budget which have been invested into tourism development

\begin{tabular}{ll}
\hline Share & Number of municipalities \\
\hline More than $40 \%$ & 1 \\
$20 \%-39,9 \%$ & 1 \\
$10 \%-19,9 \%$ & 6 \\
$5 \%-9,9 \%$ & 6 \\
$1 \%-4,9 \%$ & 10 \\
Less than $1 \%$ & 4 \\
It is not possible to identify & 3 \\
Without answer & 5 \\
\hline
\end{tabular}

Source: Authors' own elaboration, 2017

The question about the willingness of accommodation providers to pay local tourism fees were evaluated on a scale: very willing; willing, reluctant; and very reluctant. $64 \%$ of municipalities' representatives evaluated this willingness positively that means in the categories willingness plus very willingness. Greater willingness to pay local tourism taxes saw representatives of municipalities in the category of mountain resorts (where they know each other) while the smallest willingness, in the opinion municipality, showed business entities in major cities, including Prague.

\subsection{Local tourism fees - traditional accommodation providers viewpoint}

The general comment for innovation of the legal norm about the local tourism fees was that eleven out of fourteen traditional providers of accommodation establishments didn't support increasing the maximum rate of both local tourism fees. On the other hand, they supported the idea to merge two local tourism fees in one fee (11 from 14 respondents). The association supported increasing the rate and merging the fees. That means $100 \%$ of respondents, including the association, strongly supported an innovation of law towards a determination of accommodation establishments who have to pay obligatory tourism local fees. The new type of peer-to-peer accommodation providers was considered to be the main problem of the original legal norm from $100 \%$ of respondents. In the field of willingness or unwillingness to pay correctly local fees they answered $(\mathrm{H}$ (number) $=$ hotelier):

H(4): I pay the most amount (62\%) to the municipality budget from local tourism fees but I am one of the 232 providers of accommodation. Where is the rest? I will 
pay whether everybody will pay. (note: The biggest provider in a mountain destination).

H(12): I do not pay more than half of what I should. And why? Because I do not see any reinvesting from the side of municipality into tourism - transport infrastructure, cleaning the city. Nobody asks us (hoteliers) what we need.

H(15): I will pay in case that everybody will, including Airbnb.

\subsection{Local tourism fees - collaborative economy, case study from Prague}

From the side of the collaborative economy was used and analyzed secondary data aimed to show the importance, timeliness, and acuteness to innovate Czech legal framework towards this part of the tourism market (it was shown on the example of the capital city of Prague). In June 2019 the peer-to peer accommodation supply structure in Prague was as follows: 83 \% Entire Place, $15 \%$ Private Room, and 2 $\%$ Shared Room (Airbnb and HomeAway) (AirDNA, 2020). This structure confirms that this is not the purely sharing economy based on the principle of sharing an owned room any more, but that this is the collaborative economy with the presence of digital platforms and with other newly created entrepreneurial entities. The analysis (data based on AirDNA, 2020) of the number of actively offered room nights within the Entire Place category and their occupancy rate (Fig. 1) shows that the number of supplied and demanded rooms of the Entire Place type increases. In the years 2015 and 2016 this was a continual initial increase in the supply, but from the first quarter of 2017 we can note that seasonality in the destination of Prague is typically followed, with a still moderate increase in the supply and demand.

Figure 1: The development of the Total Available Room Nights indicator in the Entire Place category and of the Booked Room Nights indicator in the Q3 2015 to Q2 2019 period in Prague

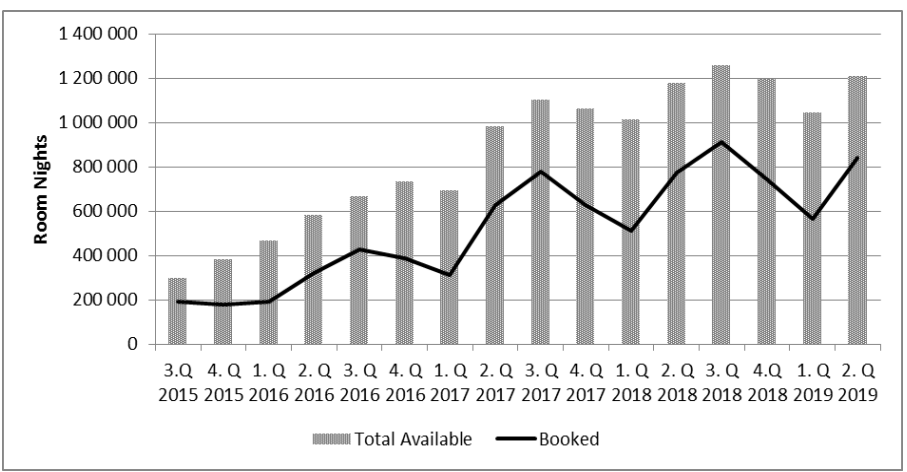

Source: Authors' own elaboration, based on AirDNA data, 2020 
What is interesting is the development of the single-bed room and studio market, where the hotel market responded to the emergence of digital platforms. As the supply of Airbnb and HomeAway increased, the hotel market began to offer more of these types of accommodation units to be competitive. While the share of the peer-to-peer accommodation supply in the total "low-capacity" rooms to let for short-term accommodation market was $69 \%$ in the middle of the year 2015, it was $65 \%$ in the first half of the year 2019 (AirDNA, 2020). However, the increase by four percent on the hotel supply side means that the total offered "lowcapacity" room capacity increased 3.3 times, while the increase in the peer-to-peer accommodation supply was only 1.8 times higher. The occupancy rate of peer-topeer accommodation was $60 \%$ on average in the period from Q3 2015 to Q2 2019, while that of single-bed room and hotel type studio capacities was $62.5 \%$. This means a considerable increase in the accommodation capacity supply to the city of Prague itself and thus also a potential increase in the number of tourists and the burden on the city.

The Revenue Per Available Room performance indicator is higher in the peer-topeer accommodation category compared with traditional hotel accommodation. In relation to Q2 2019, the peer-to-peer accommodation RevPAR in Prague is currently $\$ 78.50$, while that of hotel type accommodation in the studio and singlebed category is $\$ 62.50$ (AirDNA, 2020). Due to seasonality, the average value of the RevPAR in peer-to-peer accommodation is $\$ 55$ in the period under consideration and that of the hotel type is lower by $\$ 10$ on average. This indicates that the effectiveness of peer-to-peer accommodation is higher (being aware that hotel type accommodation offers more services and the fixed costs of hotel operation per bed are much higher than those of accommodation in a flat or a private room in a usual block of flats).

As mentioned above, the local taxation of tourism was realized through two local fees, the characteristics of which are given in Tab. 4. In the Czech Republic, about CZK 0.7 milliard (EUR 27.8 million) is collected annually (dependent on the law before innovation) concerning the two fees in direct relation to tourism (MONITOR, 2020). Fifty percent of this was revenues of the capital city of Prague and then spa type municipalities, municipalities listed on the UNESCO list, or significant mountain centers follow. From the viewpoint of the type of local fee, the amount collected as a local fee for a spa or recreational stay predominated; the reason is the more than double maximum daily rate compared with a local fee for an accommodation capacity. By the end of the year 2018, there were over 93 thousand beds available in collective accommodation facilities in Prague and over 18 million overnight stays occurred there (Czech Statistical Office, 2020). Nonresidents comprised the most overnight stays (88\%) and they spent 2.4 nights on the average in Prague (Czech Statistical Office, 2020). The development of the revenues from the two local fees (Fig. 2) in Prague shows seasonal fluctuations; the strongest period is always the $3^{\text {rd }}$ quarter of the year. 
Figure 2: Development of Tourism Local Tax Revenue in Prague 2015 - first half of 2019

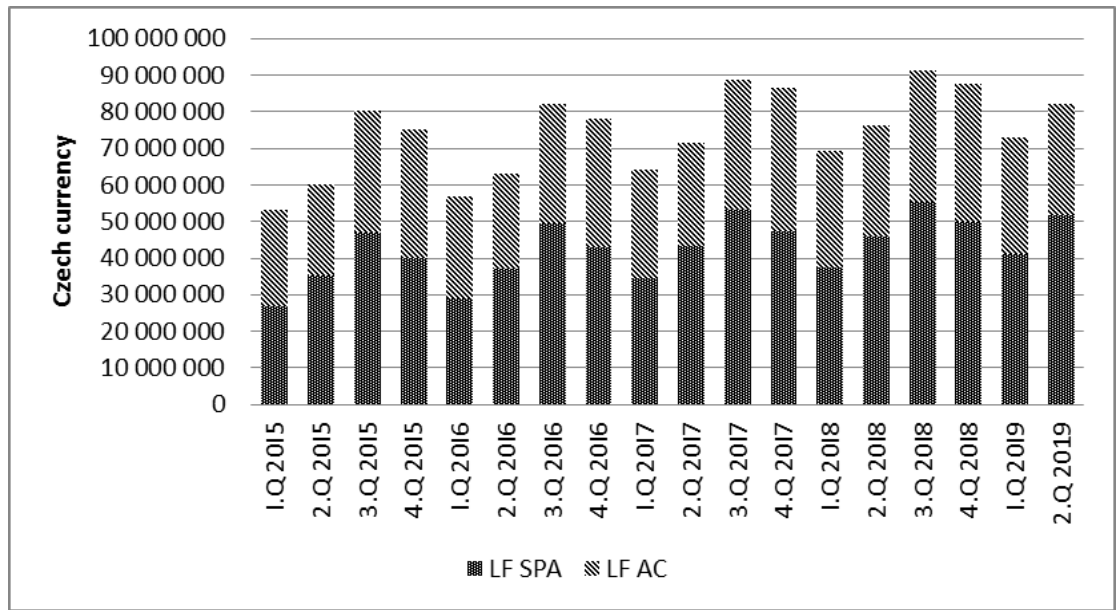

Note: LF SPA = local fee for spa or recreational stay; LF AC = local fee from accommodation capacity.

Source: Authors' elaboration, based on database MONITOR, 2020

The local fee revenues would certainly increase in cases where guests are accommodated via the Airbnb, HomeAway and other digital platforms, whether they also pay those fees. If such minimalist variant is set on the basis of the expert estimate and data from AirDNA (2020) that 2.3 guests stay overnight on average in every occupied room sold on the basis of a peer-to-peer business model in Prague, the revenue flowing to the municipality budget would increase by more than $30 \%$. In relation to an increase in the burden on the territory, which causes the need to make higher investments in the maintenance of public spaces and public services and property, it is appropriate to calculate the fee revenue per inhabitant. The local fee yield in direct relation to tourism calculated per inhabitant of Prague has increased moderately during the last three years and was EUR 9.7 at the end of the year 2018 (the average 2018 exchange rate was EUR 25.64). If the payments of local fees for peer-to-peer accommodation (irrespective of the purpose and the age structure of tourists) had been included in the yield, then the yield per inhabitant would have increased exponentially with an increase of over $200 \%$ during the last three years and the yield would be EUR 13.9 per inhabitant by the end of the year 2018 (Fig. 3, shown in the Czech currency). 
Figure 3: The revenue from the local charges and fees in direct relation to tourism per inhabitant of Prague, 2016-2018, in CZK

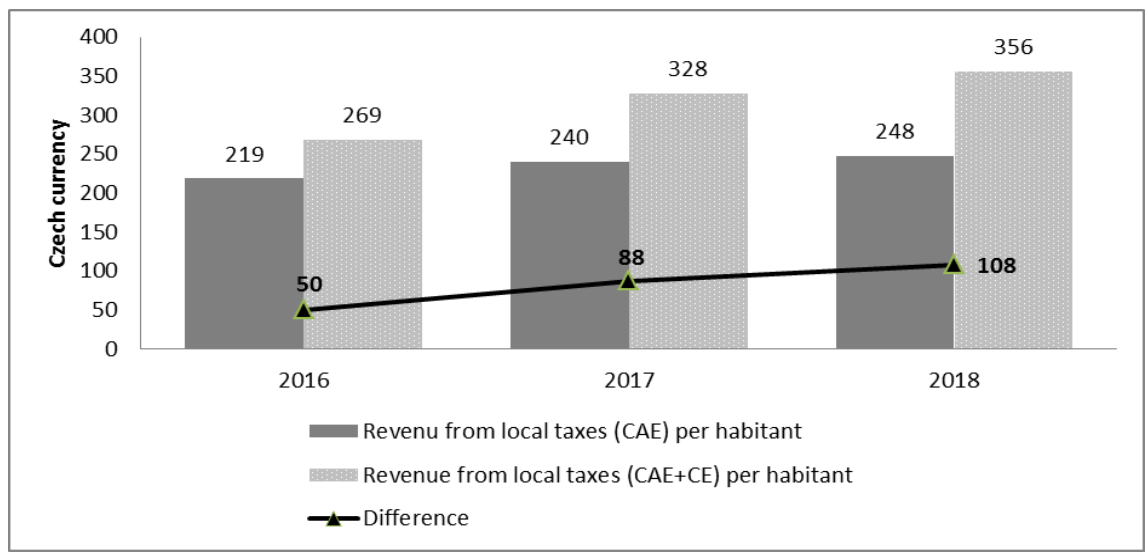

Note: $\mathrm{CAE}=$ Collective Accommodation Establishments; $\mathrm{CE}=$ Collaborative Economy Source: Authors' elaboration, based on database MONITOR, 2020 and AirDNA, 2020

\subsection{Innovation of legal norm}

Because of the unambiguous text of the act on the liability to pay a local fee for an accommodation capacity and the inappropriate categorization of groups exempted from the payment of fees in relation to the current intensity of tourism, the authors of this article have initiated the amendment of the act on local charges and fees. The innovation of the Act No. 565/1990 Coll. (2019) (from January 2020) brings that the two local fees are joined to create one local fee for a stay. The rate of this fee stays on the level of 21 Czech Crown but will increase up to $50 \mathrm{CZK} /$ person/night $=2 \mathrm{EUR}$ from January 2021 . The new local fee for a stay is possible to collect in more municipalities for any form of temporary accommodation for a consideration. The object of a newly constructed local fee for a stay is a stay for a consideration at an individual stay provider in a municipality if the length of such stay does not exceed 60 consecutive calendar days. The fee base is calculated by individual commenced days of the stay, excluding the first day of the stay. A provider may be anybody who has provided a stay for a consideration. The object of this fee is "the provision of a stay for a consideration" and not "accommodation". Although accommodation provided on the basis of an accommodation contract according to the Civil Code (2012) is one of the forms of the provision of a stay for a consideration, the object of this fee is wider to include also hidden forms of accommodation provided formally on the basis of a lease or another contract and shall also include the provision of a stay for a consideration in rooms not primarily designated for this purpose, especially in flats, ateliers, and other spaces where the final approval was given for other purposes than the provision of accommodation. A payer of a local fee for a stay is 
the person accommodated, but the payer who collects this fee for municipalities is the accommodation provider. Blind persons, holders of a disability identification card, persons under the age of 18 years and over the age of 65 years, persons hospitalized in the medical facility of an inpatient care provider, with the exception of a spa treatment rehabilitation care provider, and persons staying in the territory of a municipality in a school facility and in a facility providing social services are legally exempted from this fee for a stay.

No directive to regulate shared accommodation is expected to be issued at the European Union level. European Commission (2016) points out the fact that the sharing economy must be understood as a great opportunity for growth, innovations, and the modernization of the economy, but problems connected with dissimilar conditions for business must be expected. At the national level, especially the Ministry for Regional Development (accommodation and tourism), the Ministry of Industry and Trade, and the Office of the Government of the Czech Republic, there is the need to pay attention to the collaborative economy. Generally, regulation and/or innovations must pursue especially the interests of local inhabitants and not those of participants in tourism (tourists) and must apply to all on-line digital platforms and not only to a selected subject (such as Airbnb). The specifics of local conditions (the capital city of Prague vs. the other municipalities) must also be perceived and thus the Ministry of Finance has elaborated a draft amendment of the act on local charges and fees reflecting the increasing importance of peer-to-peer accommodation on the basis of the proposal submitted by the authors of this study. The innovation is given in Tab. 5 .

Table 5: Construction of the local fee for a stay - new innovative legal norm

\begin{tabular}{ll}
\hline Category & Local fee for accommodation \\
\hline Subject & $\begin{array}{l}\text { Payer: an accommodated guest (a natural person) } \\
\text { Payer: an accommodation provider (a natural person / legal } \\
\text { person) }\end{array}$ \\
Abject & A stay of natural persons in a municipality \\
Fee base & Up to $21 \mathrm{CZ} /$ person/day (without the stay start day) \\
Rate & Up to 50 CZK/person/day (without the stay start day) - from \\
& 01.01 .2021 \\
Flat rate charging & No \\
Local competence & The municipality in the territory of which accommodation for \\
to assess & a consideration lasting for not more than 60 consecutive \\
& calendar days is provided at an individual stay provider for a \\
& person that is not registered in the municipality \\
Fee period & No fee period - this fee is related to every overnight stay
\end{tabular}


L. Plzáková \& P. Studnička: Local Taxation of Tourism in the Context of the Collaborative Economy - Case Study from the Czech Republic

\begin{tabular}{ll}
\hline Category & Local fee for accommodation \\
\hline Liabilities of fee & An accommodation provider must keep a book of records in \\
subjects other & $\begin{array}{l}\text { writing and the records must be arranged in chronological } \\
\text { order; this book is retained for 6 years from the last entry of a } \\
\text { than pecuniary }\end{array}$ \\
\hline
\end{tabular}

Source: The Ministry of Finance of the Czech Republic, 2019

\section{Discussion}

The tax rules are different in every country and also the regulation of especially local taxes in the destinations of tourism within one state differs very frequently. It is local taxes on tourism that are what is established at regional unit level in a country concerned or even at town and municipality level. The unambiguous or not completely innovative regulation of the liability to pay local taxes on tourism often leads to losses on the side of tourism destinations. San Francisco, for example, estimates officially that they lost 35 million dollars as a result of the inadequate regulation of peer-to-peer accommodation in 2014 (Bakker \& Twining-Ward, 2018). Many exposed destinations of tourism have proceeded to take significant regulatory measures for peer-to-peer accommodation to reduce the number of tourists in the destination. Barcelona or Berlin can be given as an example. The matter is whether regulation is the right way for all destinations. Such destinations that are faced with over-tourism (Venice, Barcelona, Berlin, Dubrovnik, Hallstatt, London, and others) and are on the edge of keeping alive may have no other way. However, is not innovation better than regulation in the case of many destinations? The interest is that such destinations that live from tourism are able to find their balance between ensuring high-quality life for their residents and providing high-quality services for tourists. This means that also in these days of rapid changes and the existence of the collaborative economy all persons involved, residents and visitors, should participate in the fulfilment of the sustainable principles of life and travelling. Local taxation may be one of the tools (in addition to other non-pecuniary tools such as education) for finding the balance and sustainability of the whole social system in a destination of tourism. The relation between the collaborative economy and the fulfilment of Sustainable Development Goals in tourism is dealt with by Gössling \& Hall (2019). The matter of tax avoidances in relation to social transformation is mentioned by Frenken \& Schor (2017); they state that many owners of rented real estate avoid the payment of taxes or even do not know that they should pay taxes. This creates unfair competition with regulated business and governments thus incur losses in the form of lower tax revenues. Guttentag (2016) gives examples of towns, mostly in the USA, where an agreement about the payment of local taxes has been made between the local governments and Airbnb and even retrospectively in some towns (Matier \& Ross, 2015).

However, destinations have higher costs of the maintenance and development of public spaces and the provision of public property and services - local 
infrastructure, transport, safety and security, historical monuments, culture, local identity promotion, etc. Another research should be aimed to set a certain purpose for resources obtained by collecting local taxes, charges, and fees in tourism. In the Czech Republic the law does not establish the so-called relation to a certain purpose, which means that municipalities can use revenues from these charges and fees for financing any need of the municipality also outside the support of tourism. The relation to a certain purpose should/could be included in legislative measures or the regulation of grant titles financed from public resources aimed to support the development of tourism.

\section{Conclusions}

Both positive and negative effects of the sharing economy and/or the collaborative economy are a frequent subject of scientific articles and research in all areas of economic activities. Discussions about the manifestation of the collaborative economy in tourism are recently more frequent, especially in connection with the so-called over-tourism and the regulation of peer-to-peer accommodation. This article was aimed at contributing to this discussion from another point of view and bringing experience not with regulation but with innovation in the legislative norm in relation to peer-to-peer accommodation.

The analysis outcomes, both from the primary and secondary data, confirmed the hypothesis that development of the collaborative economy initiates the need to innovate Czech legislation in the area of setting local tourism taxes. The main problems and arguments for innovation can be seen as follows:

- The original legal form didn't reflect the rapid development of the collaborative economy based on digital platforms. The wording of the original law was discriminatory and did not cover new types of peer-to-peer accommodation. They were not obligated to pay local fees if they didn't want to pay.

- There exists some negative linear causality between both groups: traditional providers and the new ones. It means, if you don't pay, me neither. Outcomes of that relation have a negative impact on the municipality budget and on the relationship between tourists and residents.

- The other issue, which negatively influenced the willingness to pay local fees, is the fact that the collected money generated from local tourism fees must not be reinvested in the support of the development of tourism in a specific territory. That demotivated the payers, mainly providers of accommodation establishments.

- Providers of accommodation services agree with the innovation of legal form mainly due to the settlement of conditions in the tourism market and secondary data analysis showed in the Prague example that municipalities, without the innovation, lost a lot of money which came from the tourism local fees. 
Based on founded problems and all arguments, authors proposed the innovation in the act on local charges and fees and Czech Government approved it from the $1^{\text {st }}$ of January 2020. This innovation brings Czech municipalities many simplifications and benefits, especially: i) the simplification of administration; ii) a higher number of municipalities that can introduce and collect a local fee for a stay, which will result in increased municipality budget revenues; iii) enhanced powers of decision of municipalities in the regulation and collection of a local fee for a stay; iv) extended groups of facilities used for temporary accommodation for a consideration to which the part concerning a local fee for a stay of the act on local charges and fees explicitly applies. Apartment housing and the short-term lease of flats within the collaborative economy are already clearly included in the duty to demand a local fee from clients and then pay it to the budgets of the municipalities in the territory of which the object is situated by the regulation of the act; and v) reduced groups of persons exempted from the payment of a local fee.

Development in the peer-to-peer accommodation market was demonstrated using the capital city of Prague, where the growing supply and demand for this type of accommodation are clearly visible. The presented model situation shows the financial resources that were lost by Prague due to the fact that the act on local charges and fees was obsolete and not prepared for impacts of the collaborative economy especially in the area of peer-to-peer accommodation. The previous legislative regulation said that a local fee for an accommodation capacity was paid in objects designated for short-term accommodation. Apartment flats (widespread especially in mountain areas in the Czech Republic) or flats, studios, or rooms offered via digital platforms within the collaborative economy are not of this type. In this case the clear interpretation of the act requires only a slight, but significant change, i.e. to change the word "designated" to the word "used".

The aim of innovation in the legislative norm is to redistribute fairly the responsibility for the use of public spaces, property and services in towns and municipalities between residents and visitors so that their coexistence is broadly sustainable. However, local self-government must have sufficient financial resources to be able to do so. In addition to or instead of innovations, many towns proceed to regulate peer-to-peer tourism business. The question is to what extent and by which time regulations will work and whether the new model of peer-topeer trading is not natural development reflecting changes in industry, services, and the society. Future can be seen and supported more in innovations and diversification then in global regulations. Authors will monitor, analyze, and evaluate the contributions of innovated law of the local taxes in the Czech Republic. 


\section{Acknowledgment:}

The outcomes submitted in this article are based on realized projects „Local charges collection analysis in relation to capacity and efficiency of accommodation and spa facilities in the Czech Republic" (contracting authority: Czech Tourism, CzT14/o/510/1236), „Impact of local charges on tourism development“ (contracting authority: Ministry for Regional Development of the Czech Republic, MMR-1489/2014-54) and „Modification proposal for local fees in direct connection to tourism industry“ (contracting authority: Ministry for Regional Development of the Czech Republic, MMR-192/201654). Based on these projects the novelty of Act 565/1990 Coll. on local fees, was proposed by the author as well as the Certified Methodology to the amendment to Act No. 565/1990 Coll. (contracting authority: Ministry for Regional Development of the Czech Republic, MMR-1667/2016-54).

\section{References:}

Act No. 565/1990 Coll. (2019) Law on local charges and fees, available at: https://www.zakonyprolidi.cz/cs/1990-565 (January 21, 2020).

Afonso, W. (2016) The Equity of Local Sales Tax Distributions in Urban, Suburban, Rural, and Tourism Rich Counties in North Carolina, Public Finance Review, 44(6), pp. 691 721, https://doi.org/10.1177/1091142115588976.

Airbnb (2019) Taxes, available at: https://www.airbnb.cz/help/article/2509/vekter\%C3\%BDch-oblastech-se-o\%C2\%A0v\%C3\%BDb\%C4\%9Br-a\%C2\%A0odvoddan\%C4\%9B-z\%C2\%A0obsazenosti-star\%C3\%A1-airbnb (August 4, 2019).

AirDNA (2020) Market Summary Report - Prague (AirDNA).

Bakker, M. \& Twining-Ward, L. (2018) Tourism and the Sharing Economy: Policy and Potential of Sustainable Peer-to-Peer Accommodation (Washington, DC: World Bank), available at: http://hdl.handle.net/10986/30452 (November 12, 2019).

Bauwens, M., Mendoza, N. \& Iacomella, A. (2012) Synthetic overview of the collaborative economy, (P2P Foundation), available at: http://p2p.coop/files/reports/collaborativeeconomy-2012.pdf (July 25, 2019).

Benoit, S., Baker, L. T., Bolton, N. R., Gruber, T. \& Kandampully, J. (2017) A triadic Framework for collaborative consumption (CC): Motives, activities and resources \& capabilities of actors, Journal of Business Research, 79(C), pp. 219-227, https://doi.org/10.1016/j.jbusres.2017.05.004.

Botsman, R., \& Rogers, R. (2011) What's mine is yours: how collaborative consumption is changing the way we live (London: Collins).

Botsman, R. (2014) Sharing is not just for start-ups, Harvard Business Review, 92(3), pp.23-26.

Burns, S. (2010) Local authorities, funding tourism services and tourist taxes, Local Economy, 25(1), pp.47-57, https://doi.org/10.1080/02690940903545398.

Caldieraro, F., Zhang, J. Z., Cunha, M., Jr. \& Shulman, J. D. (2018) Strategic Information Transmission in Peer-to-Peer Lending Markets, Journal of Marketing, 82 (2), pp. 42-63, https://doi.org/10.1509/jm.16.0113.

Civil Code (2012) Civil Code of the Czech Republic Act No. 89/2012 Coll., available at: http://obcanskyzakonik.justice.cz/images/pdf/Civil-Code.pdf (January 21, 2020). 
L. Plzáková \& P. Studnička: Local Taxation of Tourism in the Context of the Collaborative Economy - Case Study from the Czech Republic

Coté, J. (2012) Airbnb, other sites owe city hotel tax, San Francisco Chronicle, available at: https://www.sfgate.com/bayarea/article/Airbnb-other-sites-owe-city-hotel-tax-S-Fsays-3457290.php, (July 31, 2019).

Councilof Europe (1985) European Charter of Local Self-Government, available at: http://myop.wz.cz/pdf/evropska.pdf (August 8, 2019).

Czech Statistical Office (2020) Tourism data, available at: https://www.czso.cz/ (January 20, 2020).

Dolnicar, S. (2019) A review of research into paid online peer-to-peer accommodation Launching the Annals of Tourism Research cured collection on peer-to-peer accommodation, Annals of Tourism Research, 75, pp. 248-264, https://doi.org/10.1016/j.annals.2019.02.003.

Dredge, D., \& Gyimóthy, S. (2017) Collaborative economy and tourism: Perspectives, politics, policies and prospects (Cham: Springer).

European Commission (2016) A European agenda for the collaborative economy, available at: https://ec.europa.eu/transparency/regdoc/rep/1/2016/EN/1-2016-356-EN-F1-1.PDF (August 30, 2019).

European Tourism Association (2012) Tourist tax rates, available at: https://www.etoa.org/destinations/tourist-tax-rates/ (August 14, 2019).

Einav, L., Farronota, Ch. \& Levin, J. (2016) Peer-to-Peer Markets, Annual Review of Economics, 8, pp. 615-635, https://doi.org/10.1146/annurev-economics-080315-015334.

Felson, M. \& Spaeth, J. L. (1978) Community structure and collaborative consumption: A routine activity approach, American Behavioural Scientist, 21(4), pp. 614-624, https://doi.org/10.1177/000276427802100411.

Frenken, K. \& Schor, J. (2017) Putting the sharing economy into perspective, Environmental Innovation and Societal Transitions, 23, pp. 3-10.

Gössling, S. \& Hall, C., M. (2019) Sharing versus collaborative economy: how to align ICT developments and the SDGs in tourism?, Journal of Sustainable Tourism, 27(1), pp. 74-96, https://doi.org/10.1080/09669582.2018.1560455.

Gansky, L. (2010) The mesh: Why the future of business is sharing (New York: Penguin).

Gössling, S. \& Hall, C., M. (2019) Sharing versus collaborative economy: how to align ICT developments and the SDGs in tourism?, Journal of Sustainable Tourism, 27(1), pp. 74-96, https://doi.org/10.1080/09669582.2018.1560455.

Gricar, S, \& Bojnec, S. (2017) Tourism price causalities: Case of an Adriatic country, International Journal of Tourism Research, 20, pp. 82-87, https://doi.org/10.1002/jtr.2163.

Guttentag, D. (2016) Why tourists choose Airbnb: A motivation-based segmentation study underpinned by innovation concepts (Waterloo, Ontario, Canada), available at: https://uwspace.uwaterloo.ca/bitstream/handle/10012/10684/Guttentag_Daniel.pdf (August 21, 2019).

Guttentag, D. (2017) Regulating Innovation in the Collaborative Economy: An Examination of Airbnb's Early Legal Issues, In: Dredge, D., \& Gyimóthy, S. (eds.) Collaborative economy and tourism: Perspectives, politics, policies and prospects (Cham: Springer).

Jensen, T. C. \& Wanhill, S. (2002) Tourism's taxing times: value added tax in Europe and Denmark, Tourism Management, 23(1), pp. 67-79, https://doi.org/10.1016/S02615177(01)00067-X.

Kaplan, R., A. (2014) Regulation and the Sharing Economy, New York Law Journal, 252(12), available at: https://www.paulweiss.com/media/2561266/21july14_nylj.pdf (July 18, 2019). 
Kaplan, R. \& A. Nadler, M., L. (2017) Airbnb: A Case study in Occupancy Regulation and Taxation, University of Chicago Law Review Online, 82(1), pp. 103-115.

Karlsson, L. \& Dolnicar, S. (2016) Someone's Been Sleeping in My Bed, Annals of Tourism Research, 58, pp. 159-162, https://doi.org/10.1016/j.annals.2016.02.006.

Lamberton, C. \& Rose, R. L. (2012) When is ours better than mine? A framework for understanding and altering participation in commercial sharing systems, Journal of Marketing, 76 (4), pp. 109-125, https://doi.org/10.1509/jm.10.0368.

Mak, J. (2006) Taxation of travel and tourism, In: Dwyer, L. \& Forsyth, P. (eds.) International Handbook on the Economics of Tourism (Celtenham: Edward Elgar Publishing Ltd.).

Matier, P. \& Ross, A. (2015) Airbnb pay tax bill of tens of millions to S.F. The San Francisco Chronicle,February 18, 2015.

Ministry of Finance of the Czech Republic (2019) Snémovna schválila novelu narovnávajici trh s krátkodobým ubytováním, available at: https://www.mfcr.cz/cs/aktualne/tiskove-zpravy/2019/snemovna-schvalila-novelunarovnavajici-35473 (August 5, 2019).

MONITOR (2020) MONITOR - database of Ministry of Finance of the Czech Republic, available at: https://monitor.statnipokladna.cz/ (January 18, 2020).

Palmer, T. \& Riera, A. (2003) Tourism and environmental taxes. With special reference to the "Balearic ecotax", Tourism Management, 24(6), pp. 665-674, https://doi.org/10.1016/S0261-5177(03)00046-3.

Palmer-Tous, T., Riera-Font, A. \& Rosselló-Nadal, J. (2007) Taxing tourism: The case of rental cars in Mallorca. Tourism Management, 28(1), pp. 271-279, https://doi.org/10.1016/j.tourman.2005.11.015.

Pelc, V. (2012) Mistní poplatky - praktická přiručka pro obce (Prague: C. H. Beck).

Radvan, M. (2012) Local taxes (Prague: Wolters Kluwer).

Ranson, G. (2014) Comparison of tax reliefs, tourist taxes and VAT thresholds in Europe, available at: www.cuttourismvat.co.uk/wp-content/uploads/2013/08/140614-EUTourism-tax-comparison-tables-Final.pdf (August 15, 2019).

Saptomo, A. (2017) The enactment and legal implication of tourism tax through the water resource management for increasing the local revenue: A comparison between Indonesia and advanced countries, International Journal of Civil Engineering and Technology, 8(9), pp. 844-851.

Sheng, L. (2011) Taxing tourism and subsidizing non-tourism: A welfare-enhancing solution to "Dutch disease?", Tourism Management, 32(5), pp. 1223-1228, https://doi.org/10.1016/j.tourman.2010.09.009.

Wirtz, J., Kam Fung So, K., Mody, M., Liu, S. \& Chun, H. (2019) Platforms in the Peerto-Peer Sharing Economy, Journal of Service Management, 30(4), pp. 452-483, https://doi.org/10.1108/JOSM-11-2018-0369.

Zervas, G., Proserpio, D. \& Byers, J. W. (2017) The rise of the sharing economy: estimating the impact of Airbnb on the hotel industry, Journal of Marketing Research, 54(5), pp. 687-705, https://doi.org/10.1509\%2Fjmr.15.0204. 